\title{
Study on the Expansion of a Cement-Based System Containing Sap Polymer and Supplementary Cementing Materials
}

\author{
Tatiana L. Ávalos-Rendón*, Carlos Javier Mendoza
}

Instituto de Ingeniería, Coordinación de Ingeniería Estructural, Universidad Nacional Autónoma de México, Circuito Escolar s/n, Cd. Universitaria, Coyoacán, México D. F., Mexico

Email: *TAvalosR@iingen.unam.mx

How to cite this paper: Ávalos-Rendón, T.L. and Mendoza, C.J. (2017) Study on the Expansion of a Cement-Based System Containing Sap Polymer and Supplementary Cementing Materials. Materials Sciences and Applications, 8, 123-134.

https://doi.org/10.4236/msa.2017.82008

Received: December 16, 2016

Accepted: February 3, 2017

Published: February 6, 2017

Copyright (ㅇ 2017 by authors and Scientific Research Publishing Inc. This work is licensed under the Creative Commons Attribution International License (CC BY 4.0).

http://creativecommons.org/licenses/by/4.0/

\begin{abstract}
In this paper, the addition of admixed superabsorbent polymer (SAP) improved the microstructure and durability-related properties in a cement-based system with supplementary materials. This is an important issue in real construction projects when good durability properties are required. This study investigates the effect of SAP on the systems using cement replacement by fly ash and silica fume considering the strength properties and durability properties of paste under sulfate attack of cement-based system. The replacement considered in the study was of $10 \%$ silica fume and $20 \%$ fly ash in each case, the dosage of SAP was $0.25 \%$ of the total amount of cementitious material. The results showed that the addition of SAP in the cement-based system improved the compressive strength and reduced expansion to sulfate attack. Scanning electron micrographs showed that utilization of fly ash with silica fume and silica fume with SAP resulted in a much denser microstructure, thereby, leading to an increase in compressive strength and lower expansion under sulfate attack.
\end{abstract}

\section{Keywords}

SAP Polymer, Supplementary Materials, Sulfate Attack, Durability

\section{Introduction}

Concrete is a fundamental component of modern civil engineering structures, nevertheless, its durability can be a problem affecting the efficiency of structures and involving significant repair costs. Sulfate attack is one of the most aggressive environmental deteriorations that affect the durability of concrete structures. The development of cements and concretes capable of resisting sulfate attack has 
been a long-time research objective [1] [2] [3]. Degradation of cementitious systems exposed to sulfate salts is the result of sulfate transport through the pore system, chemical reaction with the hydration product phases presenting generation of stresses due to the creation of the expansive reaction products, and the mechanical response (typically spalling and cracking) of the bulk material due to these stresses [4].

Large numbers of studies have shown that pozzolanic materials have been widely used as a substitutes for Portland cement (PC) in many applications, because of their advantageous properties, which include cost reduction, improved workability, reduction in heat of hydration, decreased permeability and increased chemical resistance [5] [6]. One practically relevant degradation process is the external sulfate attack, characterized by the ingress of sulfate ions from the surrounding medium, finally leading to expansions, cracking, spalling and eventually to the complete disintegration of the material. The partial replacement ( $5 \%$ to $30 \%$ by mass) of Portland cement using supplementary cementitious materials such as fly ash, blast furnace slag and silica fume, has been shown to improve the durability properties of blended cements [3] [5]. When pozzolanic materials are combined with PC, the normal Portland cement hydration reaction takes place but other chemical reactions also occur. The pozzolanic reaction, reactive siliceous and aluminous phases react with calcium hydroxide $\left(\mathrm{Ca}(\mathrm{OH})_{2}\right.$ or $\mathrm{CH})$ generated by the cement hydration, forming extra calcium-silicate-hydrate (C-S-H or CSH), and causing a refinement in the pore structure, thus, impeding the penetration and movement of potentially aggressive ions such as $\mathrm{H}^{+}, \mathrm{Cl}^{-}$and $\left(\mathrm{SO}_{4}\right)^{2-}$. At the same time, the amount of portlandite $(\mathrm{CH})$ is reduced in the hardened paste, in consequence, more strength-giving material is produced and less portlandite can be leached out during chemical attack [1] [7] [8].

When a material becomes as integral to the structure as concrete, it is important to analyze its environmental impacts to conclude if the material is sustainable. Supplementary cementing materials have proven to be economical, environmental alternatives to typical concrete mixes. The use of supplementary cementing materials has allowed a significant reduction in carbon dioxide $\left(\mathrm{CO}_{2}\right)$ emissions in cement production, as the amount of Portland cement can be reduced in the concrete [6]. The replacement of PC with pozzolanic materials reduces the overall $\mathrm{CO}_{2}$ footprint of the material.

In recent years, one of the relatively new developments is based on the application of Superabsorbent Polymers (SAP) as internal curing agents. Superabsorbent polymers are cross-linked polyelectrolytes, which start to swell upon contact with water or aqueous solutions, resulting in the formation of a hydrogel. This process is reversible, so the removal of water results in collapsing of SAPs. Because of this excellent properties, SAP has been widely used in many fields, especially in personal care products, food preservatives, medical, agriculture, forestry, horticulture, and daily necessities etc., and may have wide application in cement-based materials for the construction [9]. SAP has been found to successfully improve the microstructure of high strength concrete and is increa- 
singly applied in real construction projects. In cementitious matrices of fresh/young materials, they form a system of evenly distributed pores filled with water, which can be gradually released during hydration process, thus preventing self-desiccation. The principle of internal curing with SAP relates to the provision of water-filled cavities in the hardened cement paste and it is, for example, used to reduce autogeneous shrinkage in concretes with low water/binder ratios. Absorption of a SAP is strictly dependent on the concentration of ions in the swelling medium because the main driving force for the swelling of SAPs is the osmotic pressure which is proportional to the concentration of ions in the aqueous solution. Di and trivalent ions $\left(\mathrm{Ca}^{2+}, \mathrm{Al}^{3+}\right)$ have an additional effect on the swelling behavior of SAPs, as they are based on polyacrylates, moreover, because of their complex formation with carboxylate groups they act as additional cross-linkers, dramatically reducing the absorption capacity. The traditional superabsorbents showed poor resistance to salt as evidenced by their notable low absorbency in electrolytic solutions [9] [10] [11].

The use of SAP in building materials is relatively recent. Scarce information is available on the use of SAP to improve the microstructure and durability-related properties of pastes of normal strength made with supplementary cementitious materials. This study was initiated to investigate the influence of SAP in a cement-based system with supplementary materials considering the effect on strength, porosity and durability properties.

\section{Experimental Procedure}

The materials used in the preparation of the mixes were fly ash (FA), silica fume (SF), and Portland cement type II. Fly ash, obtained from the CFE Carboelectric plant in Rio Escondido, Coahuila, as a subproduct has a total sum of $\mathrm{SiO}_{2}, \mathrm{Al}_{2} \mathrm{O}_{3}$ and $\mathrm{Fe}_{2} \mathrm{O}_{3}$, which totalizes 93.3\%. Silica fume (SF) was obtained from Sika. The chemical determinations specified in ASTM 618 "Standard Specification for Fly ash and Raw of Calcined Natural Pozzolan for Use as Mineral Admixture in Portland Cement Concrete" are shown in Table 1. X-ray diffraction (XRD) patterns are shown in Figure 1. The superabsorbent polymer (SAP) was supplied by SNF Floerger. This polymer consisted of a covalently cross-linked copolymer of acrylamide and acrylic acid, and has an absorption capacity of $300-350 \mathrm{ml} / \mathrm{g}$ in demineralized water, measured by the "tea bag" method [12]. The Portland cement was supplied by CEMEX.

$\mathrm{X}$-ray diffraction patterns were carried out on a diffractometer Bruker AXS D8 Advance coupled to a copper anode X-ray tube. Compounds were conventionally identified by the corresponding Joint Committee Powder Diffraction Standards (JCPDS). We determined morphology by scanning electron microscopy using a Stereoscan 440, Leica-Cambridge microscope. Compressive strength was measured on $50 \mathrm{~mm}$ cubes, utilizing a Universal Testing Machine, SATEC. Three specimens were tested for each age. Porosity was measured by the Archimedean water immersion method [13].

Seven mixtures were prepared and used in this study as presented in Table 2. 
The w/c ratio was 0.55 in all mixtures. Silica fume was added as a partial replacement of the cement at a level of $10 \%$ by weight of the total cementitious material. Fly ash was also added as a partial replacement of the cement at a level of $20 \%$ by weight of the total cementitious material. Dosage of SAP was $0.25 \%$ of the total amount of cementitious material. The mixtures were prepared with the following method: Portland cement or cement/supplementary material was add to the water and mixed for 1 minute at speed of $140 \mathrm{rpm}$, then the previously hydrated SAP was add and mixed for 1 minute, finally the paste was placed into the molds. Mix designation is based on the amount of SF and FA present, e.g. SF10FA20 indicates $10 \%$ SF and 20\% FA. Specimens utilized in the study were $50 \times 50 \mathrm{~mm}$ paste cubes, which were used to measure the compression strength and porosity. Cement bars $(25 \times 350 \mathrm{~mm})$ specimens were used to measure length periodically to calculate the sulfate attack expansion. Fresh paste was poured into oiled molds, covered with plastic sheeting, and placed at room temperature. The mold was removed after $24 \mathrm{~h}$, afterwards, all the specimens were stored in a lime-saturated water solution tank for an initial moist curing period of 7, 14, 28 and 91 days. To determine the sulfate resistance, we immersed samples at the age of 28 days in a $5 \%$ sodium sulfate $\left(\mathrm{Na}_{2} \mathrm{SO}_{4}\right)$ solution and measured their length periodically to obtain the expansion. The sulfate solution was replaced whenever the $\mathrm{pH}$ value exceeded 9.5. The degree of sulfate attack was evaluated by measuring the expansion of samples [14] [15].

Table 1. Chemical compositions of Portland cement, fly ash and silica fume.

\begin{tabular}{|c|c|c|c|}
\hline & Portland Cement (\%) & Fly Ash (\%) & Silica Fume (\%) \\
\hline \multicolumn{4}{|l|}{ Oxide } \\
\hline $\mathrm{SiO}_{2}$ & 17.2 & - & 81.9 \\
\hline $\mathrm{Al}_{2} \mathrm{O}_{3}$ & 5.1 & - & 0.9 \\
\hline $\mathrm{Fe}_{2} \mathrm{O}_{3}$ & 2.9 & - & 0.3 \\
\hline $\mathrm{SiO}_{2}+\mathrm{Al}_{2} \mathrm{O}_{3}+\mathrm{Fe}_{2} \mathrm{O}_{3}$ & - & 93.3 & \\
\hline $\mathrm{CaO}$ & 57.8 & - & 2.6 \\
\hline $\mathrm{MgO}$ & 1.4 & - & 0.5 \\
\hline $\mathrm{Na}_{2} \mathrm{O}$ & 0.60 & 0.9 & 0.62 \\
\hline $\mathrm{K}_{2} \mathrm{O}$ & 0.70 & - & 0.54 \\
\hline $\mathrm{SO}_{3}$ & 4.1 & 0.4 & 0.1 \\
\hline $\mathrm{CaO}$ free & 0.5 & - & \\
\hline Loss on ignition (LOI) & 4.7 & 2.4 & 2.8 \\
\hline \multicolumn{4}{|l|}{ Bogue compounds } \\
\hline $\mathrm{C}_{3} \mathrm{~S}$ & 54.48 & - & - \\
\hline $\mathrm{C}_{2} \mathrm{~S}$ & 8.21 & - & - \\
\hline $\mathrm{C}_{3} \mathrm{~A}$ & 8.6 & - & - \\
\hline $\mathrm{C}_{4} \mathrm{AF}$ & 8.82 & - & - \\
\hline
\end{tabular}



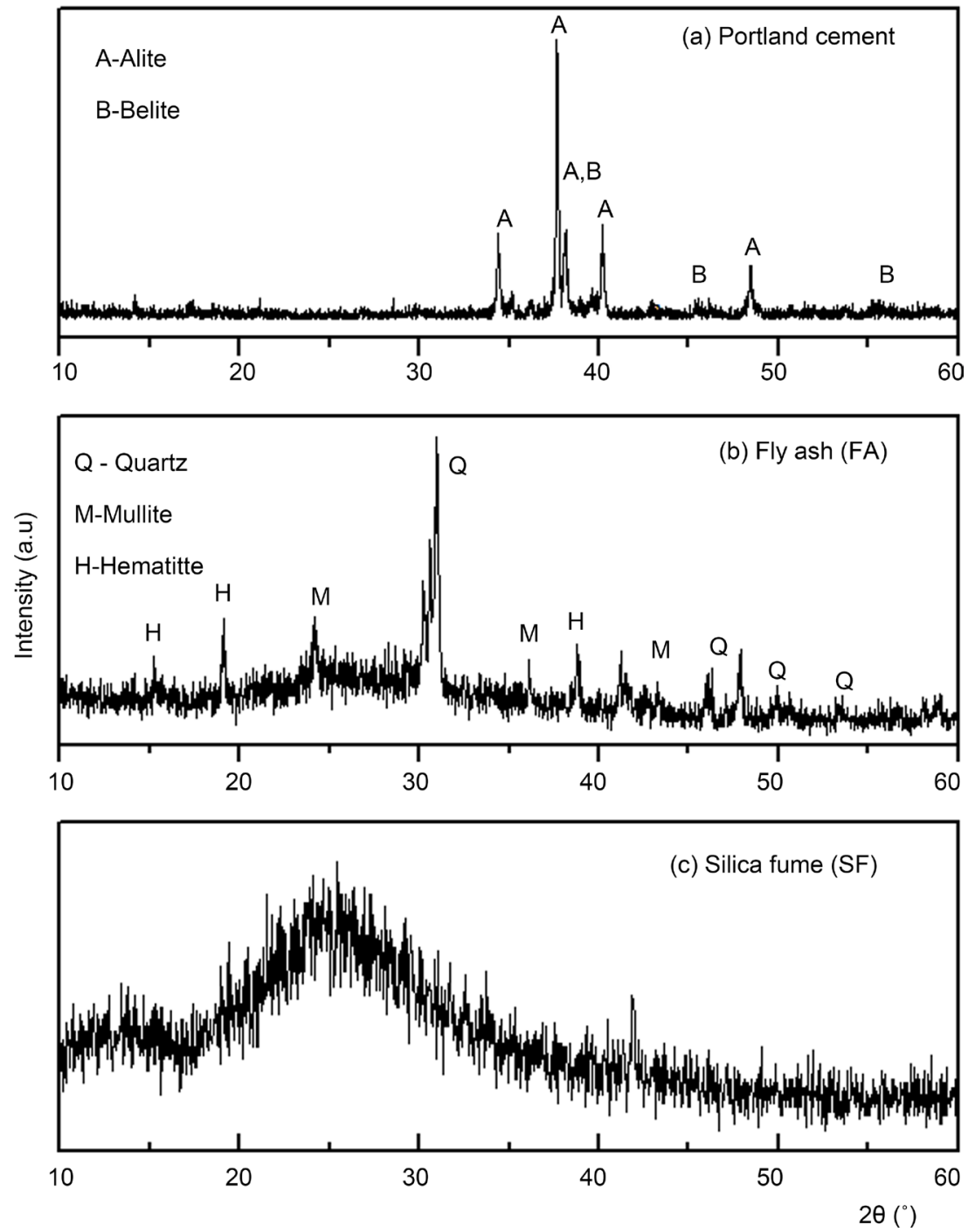

Figure 1. XRD patterns of (a) Portland cement, (b) Fly ash and (c) Silica fume.

Table 2. Mixtures proportion.

\begin{tabular}{cccccc}
\hline Mix & W/C & Cement (\%) & SF (\%) & FA (\%) & SAP (\%) \\
\hline 1 C & 0.55 & 100 & - & - & - \\
2 SF10 & 0.55 & 90 & 10 & - & - \\
3 FA20 & 0.55 & 80 & - & 20 & - \\
4 SF10FA20 & 0.55 & 70 & 10 & 20 & - \\
5 SF10SAP & 0.55 & 90 & 10 & - & 0.25 \\
6 FA20SAP & 0.55 & 80 & - & 20 & 0.25 \\
7 SF10FA20SAP & 0.55 & 70 & 10 & 20 & 0.25 \\
\hline
\end{tabular}

\section{Results}

\subsection{Characterization of Raw Materials}

XRD pattern of the dry cement is shown in Figure 1(a). The major components 
in cement particles are alite $\left(\mathrm{Ca}_{3} \mathrm{SiO}_{5}, \mathrm{C}_{3} \mathrm{~S}\right)$ and belite $\left(\mathrm{Ca}_{2} \mathrm{SiO}_{4}, \mathrm{C}_{2} \mathrm{~S}\right)$. The alite and belite phases constitute approximately $50 \%-70 \%$ and $8 \%-10 \%$ of the cement, respectively. In the case of fly ash, a small amorphous phase and crystalline phases as quartz, mullite and hematite, were detected. Moreover, Figure 1 (c) shows that XRD pattern of silica fume was found to exhibit generally amorphous phase. Then, morphology of the materials was obtained by SEM (Figure 2). Fly ash particles consist of clear glassy spheres with different sizes (5 $70 \mu \mathrm{m})$. Moreover, energy dispersive X-ray analysis showed low amounts of Ca, indicating a Class F fly ash. Silica fume particles were spongy agglomerates constituted by small particles (less $1 \mu \mathrm{m}$ ).

\subsection{Compressive Strength}

The compressive strength at different ages is displayed in Figure 3. Control mix (C) at all ages was found to have higher strengths than all mixes including fly ash (FA20) and fly ash with SAP (FA20SAP) showed, after 91 days of curing, 44 and
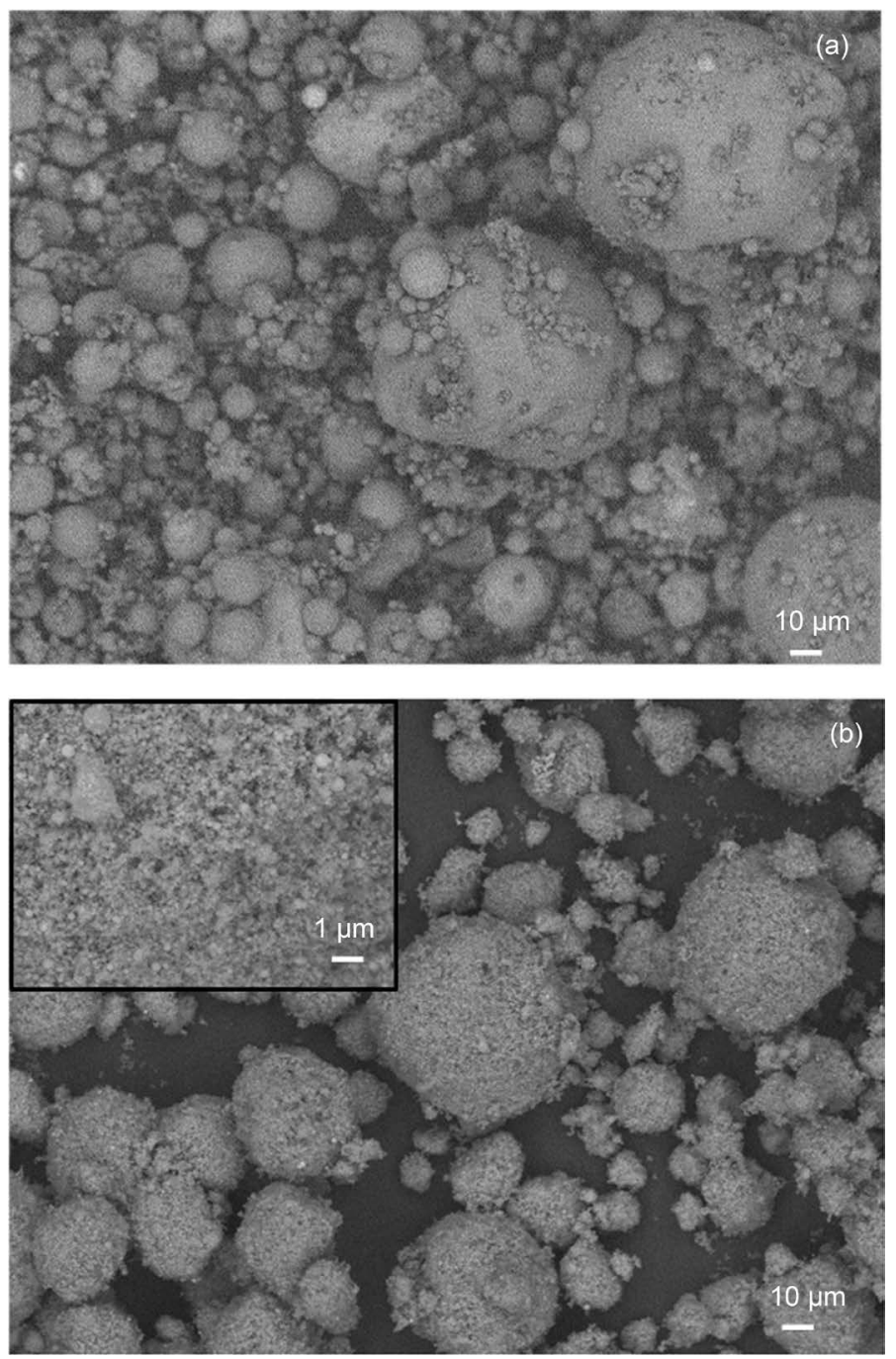

Figure 2. SEM micrographs of raw materials. (a) Fly ash and (b) Silica fume. The rectangle inset shows small particles constituting silica fume. 


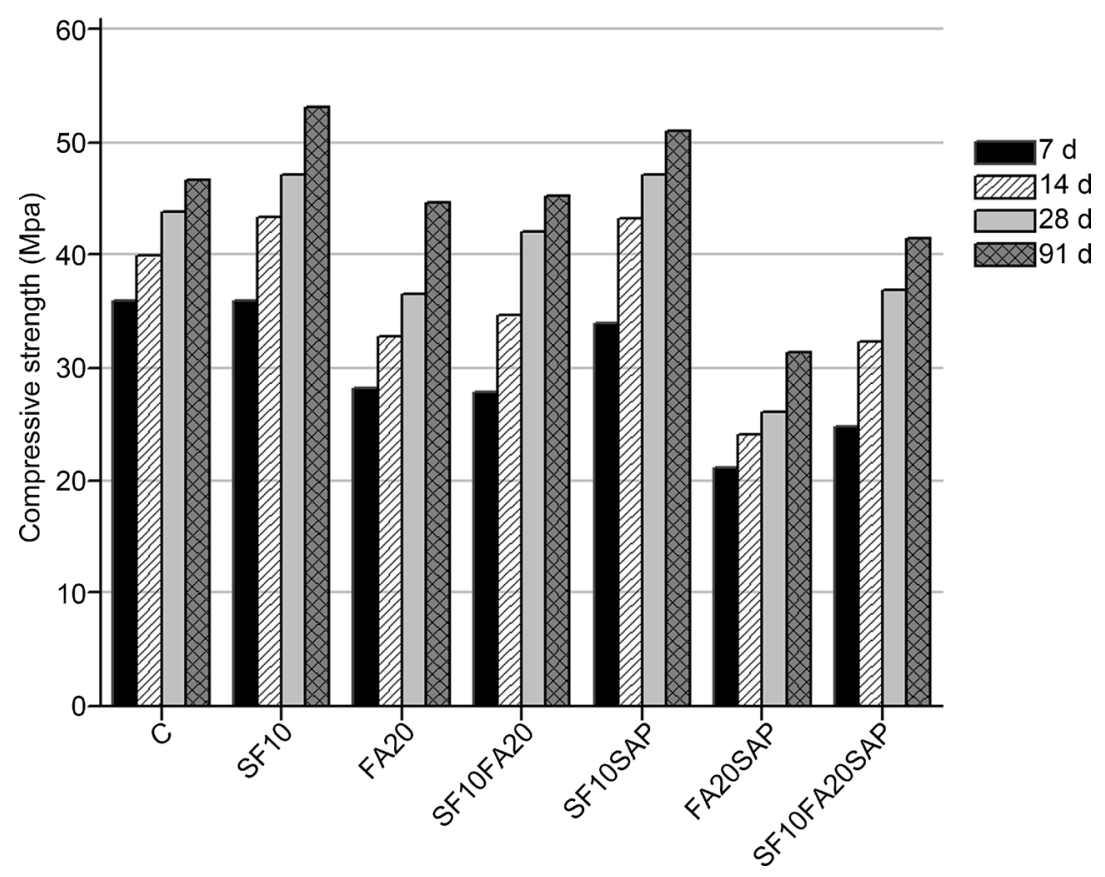

Figure 3. Compressive strength results, specimens with $\mathrm{w} / \mathrm{c}=0.55$.

$31 \mathrm{MPa}$, respectively. Fly ash is generally known to decrease strength development at early ages and is typically slower than in conventional Portland cement content, because the early age bonding of fly ash particles to the cement matrix is very weak [6] [16]. Moreover, the addition of SAP to the mix reduces the mechanical performance of cement composites due to the voids introduced in the matrix after deswelling the of SAP particles [10] [17] [18]. Nonetheless, the case of mixes with silica fume showed to attain greater strengths, especially the mixes only with silica fume (SF10) and silica fume with SAP (SF10SAP), after 91 days of curing reaching, 53 and $51 \mathrm{MPa}$, respectively. However, Silica fume is known to produce high-strength cement composites through refined pore structure. Nevertheless, presence of silica fume due to its finer particle size has a filler effect in the voids introduced in the matrix by the addition of SAP [19] [20] [21]. The compressive strength in the mixes with silica fume together with fly ash were found to have lower strengths than the control mix after 91 days of curing, 45 and $41 \mathrm{MPa}$, respectively. Mixes having silica fume together with fly ash, SF10FA20 and SF10FA20SAP, reached compressive strengths of 45 and 41.0 $\mathrm{MPa}$, respectively-a little lower than that of the control mix, $46 \mathrm{MPa}$.

\subsection{Durability and Porosity}

As shown in Figure 4, all the mixes decreased the porosity at old ages. However, the mixes with supplementary materials, SF10SAP and SF10FA20 showed lower porosity at all ages. This is because silica fume and fly ash enhance pozzolanic reaction, generating extra calcium-silicate-hydrate $(\mathrm{CSH})$ and causing a refinement in the pore structure. In the case of SF10SAP, the addition of SAP generates pores, although silica fume acts like filler, causing a dense matrix [7] [8] [18] [19]. 


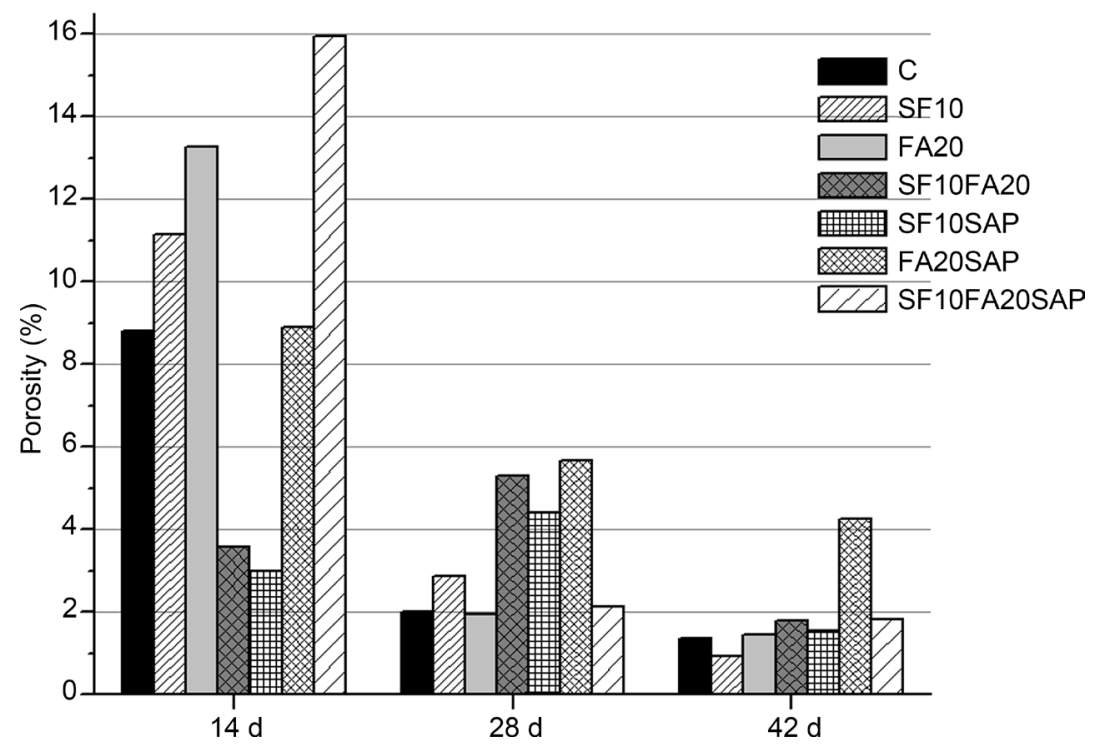

Figure 4. Porosity results of the different specimens.

Samples immersed in a sodium sulfate solution were measured at different ages to calculate the last sulfate expansion (Figure 5). The expansion of all samples increased steadily and continuously with the increase of the sulfate exposure period due to the slow and continuous intrusion of sulfate ions into specimens. Specimens containing fly ash showed higher last expansions except in presence of silica fume. Reduced sulphate resistance of samples containing fly ash has been ascribed to reaction of sulphates with $\mathrm{C}_{3} \mathrm{~A}$ or calcium-aluminate glass in the fly ash, or with calcium-aluminate hydrates (e.g., gehlenite) produced by hydration of the fly ash [16]. The addition of silica fumes to samples containing fly ash reduced expansion significantly (SF10FA20). Expansions of specimens with silica fume were lower. Samples SF10 y SF10SAP showed superior performance to the control specimen without silica fume (C). The explanation is that the silica fume acts as a filler due to its smaller particle size and the pozzolanic reaction of the SF produces additional C-S-H gel, which grows into the capillary spaces that remain after the hydration of the cement in mixes. Therefore, it would appear that $\mathrm{SF}$ acts both physically (as filler) and chemically reacting with $\mathrm{Ca}(\mathrm{OH})_{2}$ to form C-S-H to aid in the improvement of fly ash mixes [19]. Additionally, the presence of SAP causes a matrix densification and sulfate ions are not able to migrate into the cement matrix because SAP showed lower absorbency in electrolytic solutions acting as a barrier. These results are important since SF/SAP specimens show mechanical properties similar to SF specimens but have better resistance to sulphate attack.

\subsection{Microstructure (SEM)}

In order to evaluate the impact of the SF, FA and SAP plus their combination on microstructure of cement pastes, SEM images of three selected specimens are shown (Figure 6). In Figure 6(a), the microstructures were non-compact and needle-like crystals of ettringite, lying on surface and in some vacant spaces, and 
crystals of Portlandite were formed. The morphology of C-S-H in this mix was fluffy. Figure 6(b) displays that the addition of SAP reduced the porosity of the hardened cement paste. Microstructure of the paste in the vicinity of the SAP particles was obviously improved as a result of more effective hydration of cement particles under the influence of internal curing provided by SAP. The morphology of C-S-H gel was more condensed and the amount of ettringite formation was further reduced. Finally, mix containing $10 \%$ silica fume and $20 \%$ fly ash is displayed in Figure 6(c), which represented the synergistic effect of combination of silica fume and fly ash on the microstructure of the paste. Porosity is reduced because of super pozzolanic performance and the production of higher amounts of C-S-H gel, causing a slightly denser and finer structure. The filler effect of adding silica fume evidently still gives the matrix a denser microstructure while the amount of ettringite formation was reduced; crystals of Portlandite were reduced as a consequence the pozzolanic reaction.

\section{Conclusion}

From this study, it can be concluded that the utilization of silica fume (SF10), silica fume with fly ash (SF10FA20) and silica fume with SAP (SF10SAP) in paste were found to increase the compressive strength and durability properties. Moreover, the high compressive strength in these mixes was due to both the filler effect and the pozzolanic reaction of silica fume, giving a denser microstructure, thereby, resulting in a gain in strength. SAP played an important role in the control of Portlandite formation and densification of C-S-H gel through modification of its morphology. All of these phenomena observed caused a denser matrix with lower porosity. Durability properties were not affected by the addition of SAP when silica fume was contained in the mix. The reason for this

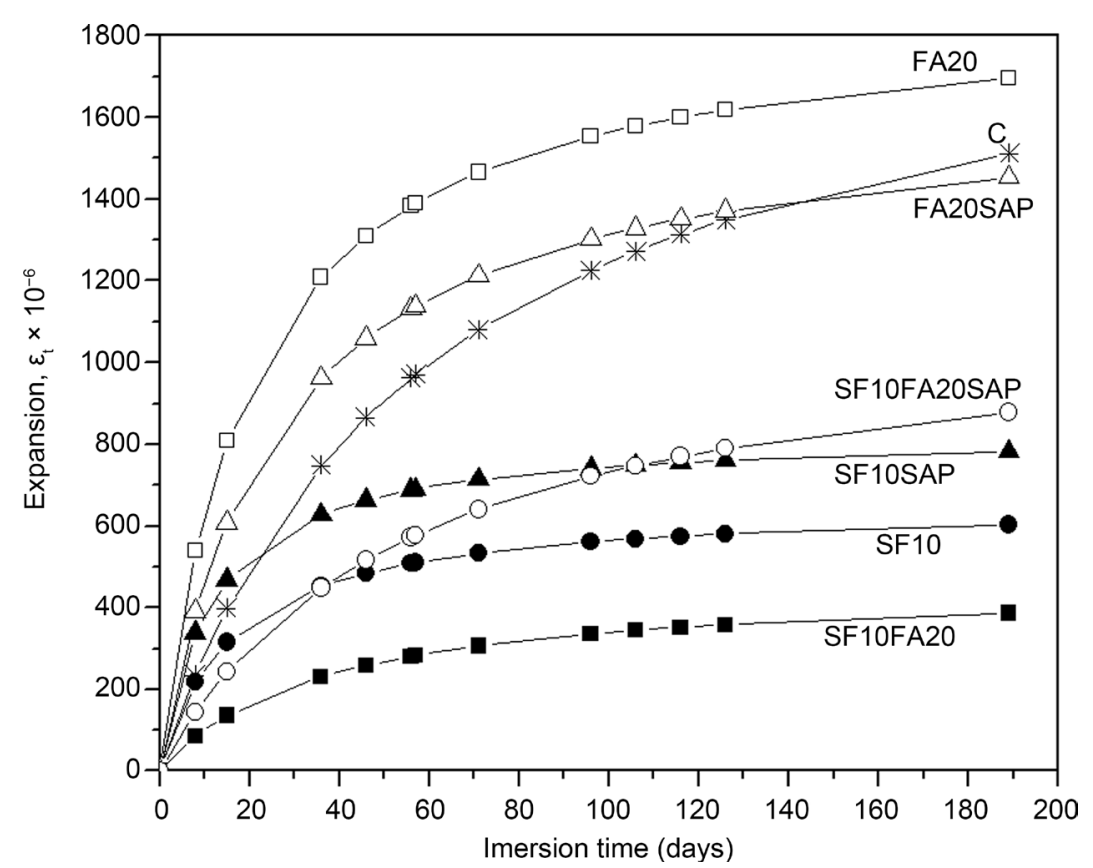

Figure 5. Expansion of different cement based-system under sodium sulfate attack. 

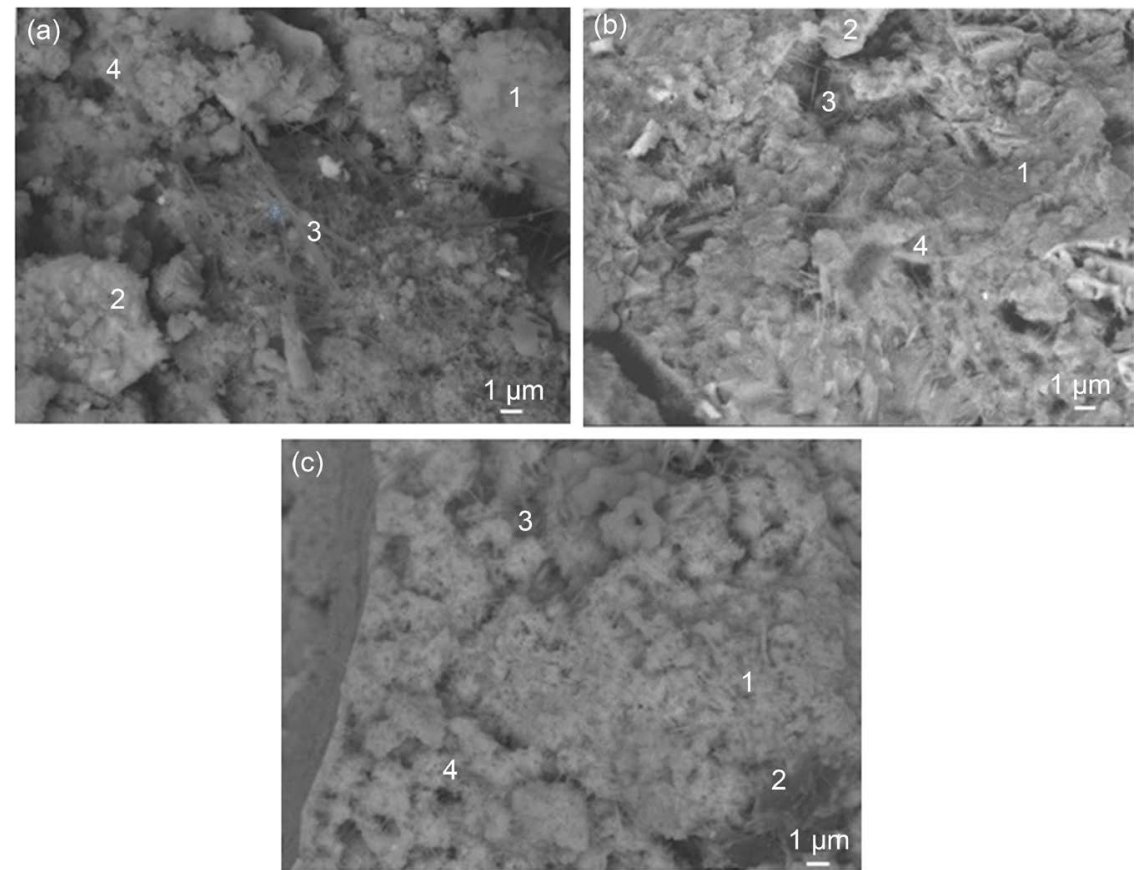

Figure 6. Microstructure of Portland (a) 10\% silica fume (b) $10 \%$ silica fume with SAP (c) $10 \%$ silica fume with $20 \%$ fly ash cement paste. $1=\mathrm{CSH}, 2=\mathrm{C}(\mathrm{OH})_{2}, 3=$ ettringite, $4=$ pore.

is an improvement in microstructure and the low absorbency of SAP in electrolytic solutions $\left(\mathrm{Na}_{2} \mathrm{SO}_{4}\right)$, causing a barrier for sulfate ions migration. However, it is observed that the SF/SAP system is a good choice when good mechanical properties and durability are required.

\section{Acknowledgements}

T. Ávalos-Rendón acknowledges DGAPA-UNAM for personal financial support. The authors would like to say thanks to Adriana Tejeda-Cruz, Omar Novelo and Raymundo Mondragon for technical help.

\section{References}

[1] Santhanam, M., Cohen, M.D. and Olek, J. (2001) Sulfate Attack Research-Whiter Now? Cement and Concrete Research, 31, 845-851. https://doi.org/10.1016/S0008-8846(01)00510-5

[2] Ouyang, C., Nanni, A. and Chang, W.F. (1988) Internal and External Sources of Sulfate Ions in Portland Cement Mortar: Two Types of Chemical Attack. Cement and Concrete Research, 18, 699-709. https://doi.org/10.1016/0008-8846(88)90092-0

[3] Donatello, S., Palomo, A. and Fernández-Jiménez, A. (2013) Durability of very High Volume Fly Ash Cement Pastes and Mortars in Aggressive Solutions. Cement and Concrete Composites, 38, 12-20. https://doi.org/10.1016/j.cemconcomp.2013.03.001

[4] Ferraris, C.F., Stutzman, P.E. and Snyder, K.A. (2006) Sulfate Resistance of Concrete: A New Approach. R \& D Serial No. 2486, Portland Cement Association, Skokie, Illinois, $93 \mathrm{p}$.

[5] Ghrici, M., Kenai, S. and Said-Mansour, M. (2007) Mechanical Properties and Durability of Mortar and Concrete Containing Natural Pozzolana and Limestone 
Blended Cements. Cement and Concrete Composites, 29, 542-549. https://doi.org/10.1016/j.cemconcomp.2007.04.009

[6] Ramezanianpour, A.A. (2014) Cement Replacement Materials. Properties, Durability, Sustainability. Springer, New York. https://doi.org/10.1007/978-3-642-36721-2

[7] Sha, W. and Pereira, G.B. (2001) Differential Scanning Calorimetry Study of Ordinary Portland Cement Paste Containing Metakaolin and Theoretical Approach of Metakaolin Activity. Cement and Concrete Composites, 23, 455-461. https://doi.org/10.1016/S0958-9465(00)00090-1

[8] de Sensale, G.R. (2010) Effect of Rice-Husk Ash on Durability of Cementitious Materials. Cement and Concrete Composites, 32, 718-725. https://doi.org/10.1016/j.cemconcomp.2010.07.008

[9] Chen, Z., Liu, M. and Ma, S. (2005) Synthesis and Modification of Salt-Resistant Superabsorbent Polymers. Reactive and Functional Polymers, 62, 85-92. https://doi.org/10.1016/j.reactfunctpolym.2004.09.003

[10] Beushausen, H., Gilmer, M. and Alexander, M. (2014) The Influence of Superabsorbent Polymer on Strength and Durability Properties of Blended Cement Mortars. Cement and Concrete Composites, 52, 73-80. https://doi.org/10.1016/j.cemconcomp.2014.03.008

[11] Mechtchreine, V. and Reinhardt, H.-W. (2012) Application of Superabsorbent Polymers (SAP) in Concrete Construction. Springer, Berlin. https://doi.org/10.1007/978-94-007-2733-5

[12] Esteves, L.P. and Jensen, O.M. (2012) Absorbency of Superabsorbent Polymers in Cementitious Environments. MRS Online Proceeding Library Archive, 1488.

[13] Kohout, T., Karlqvist, R., Lassila, I., Eskelinen, J., Hortling, A., Pesonen, L.J. and Hæggström, E. (2013) Ultrasonic Determination of Porosity in Homogeneous Ceramic Samples. Geophysica, 49, 25-32.

[14] Soroka, I. and Stern, N. (1976) Effect of Calcareous Fillers on Sulfate Resistance of Portland Cement. American Ceramic Society Bulletin, 55, 594-595.

[15] ASTM (2004) C1012-04. Standard Test Method for Length Change of HydraulicCement Mortars Exposed to a Sulfate Solution. ASTM International, West Conshohocken.

[16] Thomas, M.D.A., Shehata, M.H., Shashiprakash, S.G., Hopkins, D.S. and Cail, K. (1999) Use of Ternary Cementitious System Containing Silica Fume and Fly Ash in Concrete. Cement and Concrete Research, 29, 1207-1214. https://doi.org/10.1016/S0008-8846(99)00096-4

[17] Hasholt, M.T., Jensen, O.M., Kovler, K. and Zhutovsky, S. (2012) Can Superabsorbent Polymers Mitigate Autogenous Shrinkage of Internally Cured Concrete without Compromising the Strength? Construction and Building Materials, 31, 226-230. https://doi.org/10.1016/j.conbuildmat.2011.12.062

[18] Pourjavadi, A., Fakoopoor, S.M., Hosseini, P. and Khaloo, A. (2013) Interactions between Superabsorbent Polymers and Cement-Based Composites Incorporating Colloidal Silica Nanoparticles. Cement \& Concrete Composites, 37, 196-204. https://doi.org/10.1016/j.cemconcomp.2012.10.005

[19] Nochaiya, T., Wongkeo, W. and Chaipanich, A. (2010) Utilization of Fly Ash with Silica Fume and Properties of Portland Cement-Fly Ash-Silica Fume Concrete. Fuel, 89, 768-774. https://doi.org/10.1016/j.fuel.2009.10.003

[20] Siddique, R. and Khan, M.I. (2011) Supplementary Cementing Materials. Springer, New York. https://doi.org/10.1007/978-3-642-17866-5

[21] Githachuri, K. and Alexander, M.G. (2013) Durability Performance Potential and 
Strength of Blended Portland Limestone Cement Concrete. Cement \& Concrete Composites, 39, 115-121. https://doi.org/10.1016/j.cemconcomp.2013.03.027

Submit or recommend next manuscript to SCIRP and we will provide best service for you:

Accepting pre-submission inquiries through Email, Facebook, LinkedIn, Twitter, etc. A wide selection of journals (inclusive of 9 subjects, more than 200 journals)

Providing 24-hour high-quality service

User-friendly online submission system

Fair and swift peer-review system

Efficient typesetting and proofreading procedure

Display of the result of downloads and visits, as well as the number of cited articles Maximum dissemination of your research work

Submit your manuscript at: http://papersubmission.scirp.org/

Or contact msa@scirp.org 